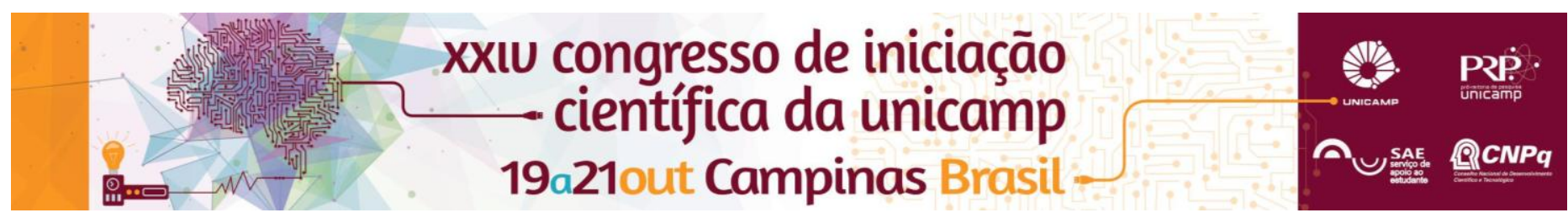

\title{
Correlação entre os fatores inerentes à produção de frangos de corte versus emissão de amônial
}

\author{
Gabriel H. Baron*, Daniella J. Moura (orientador), Juliana M. Massari (PG), Thayla M. R. C. Curi (PQ), Rimena A. \\ Vercellino (PG)
}

\section{Resumo}

O trabalho visou compreender quais fatores ambientais influenciam na produção de frangos de corte durante a criação.

Foram mensurados dados de temperatura e umidade relativa, e a qualidade da cama de frango em relação ao $\mathrm{pH} e$ umidade, os quais foram monitorados semanalmente durante um ciclo de produção. O projeto enfatizou os quesitos relacionados à cama de frango, fator importante por ser fonte de produção de amônia e sua qualidade afeta diretamente a saúde do frango e do produto final.

\section{Palavras-chave:}

Frango, Amônia, cama de frango.

\section{Introdução}

A pesquisa visou observar e avaliar a qualidade de cama de frango, com ênfase na quantidade de amônia produzida nas câmaras de observação em diferentes temperaturas, submetidas a estresse térmico uma vez por semana.

\section{Resultados e Discussão}

O presente projeto foi realizado em uma Câmara Climática e de Preferência Ambiental (CCPA), localizada no Laboratório de Conforto Térmico II, da Faculdade de Engenharia Agrícola da UNICAMP.

Experimentação do projeto de pesquisa pelo aluno: Avaliação da qualidade da cama de frangos de corte durante um ciclo de produção.

A coleta de dados foi realizada uma vez por semana durante o ciclo produtivo, em três compartimentos com 67 aves alojadas em cada um, criados em câmara climática. O primeiro compartimento foi designado como termoneutro, o segundo estava sob estresse térmico por calor, e o terceiro por frio, apenas durante 12 horas, uma vez por semana. Assim, objetivou-se também, avaliar se a qualidade da cama de frango foi comprometida com um dia de estresse térmico em dois dos compartimentos por $12 \mathrm{~h}$ seguidas. Os dados ambientais mensurados foram: temperatura do ar e umidade relativa. Já para avaliar a qualidade da cama de frango de maravalha, foram coletadas cinco amostras, sendo quatro em cada canto do quadrante/compartimento, e um no centro geométrico para os três compartimentos. Foram realizados testes para identificação do $\mathrm{pH}$ e da umidade da cama de frango, a fim de relacionar com a formação de amônia.

Os alunos também tiveram a atividade de estudar sobre o comportamento animal de diferentes espécies, por este ser um importante indicativo de bem-estar. Posteriormente, por meio de análises de vídeo de material da equipe, cada aluno desenvolveu seu etograma, conforme metodologia proposta por MASSARI et al. (2015) para suínos. Os resultados foram discutidos e foram realizadas apresentações orais individuais.

As apresentações orais foram baseadas nas revisões bibliográficas, de temas mais específicos e diretamente relacionadas ao projeto de pesquisa, no intuito de complementar ainda mais o assunto do projeto. Os tópicos estudados foram:

- Câmara termográfica;

- Análise de cama de frango;

- Musicoterapia;

- Etograma

- Qualidade da cama de frango e os substratos utilizados como cama para frangos de corte e suas características.

A revisão foi elaborada através de base de dados virtuais, como Scielo e Google Acadêmico. Além dessas bases, revistas técnicas da área, tais como Avisite, Avicultura Industrial, entre outros, foram consultadas.

Para cada tópico estudado, uma apresentação oral foi elaborada, com duração mínima de 15 minutos e máxima de 30 minutos, no intuito de aprimorar as técnicas de apresentação em público. Houve a participação do estudante no evento realizado na Faculdade de Engenharia Agrícola em parceria com a EMBRAPA Informática no dia 1 de junho de 2016, intitulado "Internet das coisas e sua influência no agrobusiness" onde foi abordado a definição do tema.

\section{Conclusões}

As atividades realizadas permitiram que a bolsista alcançasse efetivo avanço no seu perfil científico, detectando melhoras sensíveis na pesquisa de revisão bibliográfica, apresentação oral e delineamento e montagem de experimentos.

\section{Agradecimentos}

Ao CNPq pela bolsa.

MASSARI, J. M., CURI, T. M. D. C., MOURA, D. J., MEDEIROS, B. B., SALGADO, D. Behavioral characteristics of different gender division of growing and finishing swine in "wean to finish" system. Engenharia Agrícola, v.35, n.4, p.646-656, 2015. 